\title{
A sex-linked locus controls wing polymorphism in males of the pea aphid, Acyrthosiphon pisum (Harris)
}

\author{
MC Caillaud ${ }^{1,4}$, M Boutin ${ }^{2}$, C Braendle ${ }^{3}$ and J-C Simon ${ }^{2}$ \\ ${ }^{1}$ Department of Entomology, Cornell University, Ithaca NY 14853, USA; ${ }^{2}$ UMR INRA/ENSAR "Biologie des organismes et des \\ populations appliquee a la protection des plantes", B.P. 29, 35653 Le Rheu Cedex, France; ${ }^{3}$ Department of Ecology and Evolutionary \\ Biology, Princeton University, Princeton, NJ 08544, USA
}

\begin{abstract}
Discrete variation in wing morphology is a very common phenomenon in insects and has been used extensively in the past 50 years as a model to study the ecology and evolution of dispersal. Wing morph determination can be purely genetic, purely environmental, or some combination of the two. The precise genetic determinants of genetically based wing morph variation are unknown. Here we explore the genetic basis of wing polymorphism in the pea aphid, which can produce either winged or wingless males. We confirm that three types of pea aphid clones coexist in natural populations, those producing winged males only, those producing wingless males only, and those producing a mixture of both. A Mendelian genetic analysis reveals that male wing poly-
\end{abstract}

morphism in pea aphids is determined by a single locus, two alleles system. Using microsatellite loci of known location, we show that this locus is on the $\mathrm{X}$ chromosome. The existence of a simple genetic determinism for wing polymorphism in a system in which genetic investigation is possible may help investigations on the physiological and molecular mechanisms of genetically-based wing morph variation. This locus could also be used in the search for genes involved in the wing polyphenism described in parthenogenetic females and to investigate the interplay between polymorphisms and polyphenisms.

Heredity (2002) 89, 346-352. doi:10.1038/sj.hdy.6800146

Keywords: wing polymorphism; wing polyphenism; allelic switch; Mendelian genetics; microsatellites

\section{Introduction}

In a wide variety of taxa, two or more discrete morphs coexist with intermediate morphs rare or absent. Distinct phenotypes can result from expression of alternative alleles at specific loci. The resulting phenotypic variation is referred to as 'polymorphism'. Early reported examples include the single-locus polymorphism for color pattern in the snow goose Lampropeltis caerulescens (Pough, 1951) and the ladybird Harmonia axyridis (Tan, 1946). Similar genetic polymorphisms have been described for features of anatomy, life-cycle and behavior. Alternatively, production of different morphologies can be facultative and depend primarily on environmental conditions experienced by each individual as it develops. The resulting phenotypic variation is referred to as 'polyphenism'. The caste differentiation of social insects, in which alternative castes may differ drastically in morphology even though they are genetically identical, is one of the most dramatic examples of polyphenic development (Wilson, 1971; Nijhout and Wheeler, 1982).

Discrete variation in wing morphology is a very common phenomenon in insects and has been used extensively in the past 50 years as a model to study the ecology and evolution of dispersal and life history traits
(Harrison, 1980; Roff, 1986; Zera and Denno, 1997). One of the alternative morphs is winged, displays migratory tendency and has low fecundity, whereas the other morph is short winged or wingless, sedentary and highly fecund. Wing morph determination can be purely genetic, purely environmental, or some combination of the two (Roff and Fairbairn, 1991; Zera and Denno, 1997). In species that have a genetically controlled wing length, two types of genetic determination are known: single locus systems, typically with the short winged (or wingless) condition dominant, and polygenic systems (Roff, 1986; Roff and Fairbairn, 1991; Fairbairn, 1994). In a 1991 survey, single locus systems were listed for $31 \%$ of the cases of wing dimorphism reported (Roff and Fairbairn, 1991). In species that have a strictly environmentally controlled wing length, the environmental signal appears to be mediated by the endocrine system, as with other polyphenisms. It is well known, for instance, that exogenous juvenile hormone $(\mathrm{JH})$ can induce the wingless or short-winged morph in wing-polyphenic grasshoppers, crickets, and several species of Hemiptera (McCaffery and Page, 1978; Hardie and Lees, 1985; Dingle and Winchell, 1997; Zera and Denno, 1997). JH could also be the mediator in genetically controlled wing length polymorphisms. According to the threshold model, the segregating alleles could determine the titre of $\mathrm{JH}$ at some critical stages for wing morph determination (Roff, 1986; Roff and Fairbairn, 1991). If the JH titre is above a critical threshold, short winged or wingless individuals are formed. Interestingly, the pea aphid represents a rare case in which wing presence or absence is 
determined either genetically or environmentally, depending on the morph of the individual (male or parthenogenetic female, respectively).

Pea aphids (Acyrthosiphon pisum) are non-host-alternating cyclical parthenogens with a single sexual generation in the fall and many successive parthenogenetic generations from early spring to late fall. Sexual morphs (sexual females and males) are born from parthenogenetic females in the fall by a combination of cold temperatures and decreased photoperiods. Sex determination is of the $\mathrm{XX} / \mathrm{X} 0$ (female/male) type. Males are generated by an unusual oocyte division or 'mini-meiosis' in which only one $\mathrm{X}$ chromosome undergoes reduction while the other homologue is lost after failing to attach to the spindle on metaphase plate (Orlando, 1974). Recent work using molecular markers linked to sex chromosomes has demonstrated, in the aphid species Sitobion near fragariae, that the loss of one or the other $X$ is equally probable (Wilson and Sunnucks, 1997). In the spring, diapausing eggs hatch into fundatrices representing the first parthenogenetic generation. Since no recombination occurs during parthenogenesis (Blackman, 1987), each parthenogenetic genotype essentially represents a clone. Sexual females are mostly wingless (with notable exceptions, Miyazaki, 1987) but winged and wingless individuals can be found among parthenogenetic females, and among males. The production of winged morphs in parthenogenetic females is triggered by environmental stimuli such as high density, short day length, low temperature and/or poor food quality (Hardie and Lees, 1985). The wing polyphenism of parthenogenetic females is thought to be controlled by the $\mathrm{JH}$, although the evidence is equivocal (Hardie, 1980). In contrast, wing morph variation in males seems to have a clear genetic component as shown for the pea aphid by Smith and MacKay (1989). Clones of this aphid species collected in the field appeared to fall into three distinct categories. Some clones produced only wingless males, others produced only winged males, and a third category of clones produced both winged and wingless males in a 1:1 ratio.

The coexistence of alternative (ie, environmental vs genetic) control mechanisms within a single species makes the pea aphid a unique study organism for examining the interplay between polyphenisms and polymorphisms. Although they are determined by different cues, polyphenisms and polymorphisms may involve similar genetic and developmental architectures. Both could result from genetically based 'switches' which regulate the expression of morph-specific alternative sets of genes (Hazel et al, 1990; West-Eberhard, 1992; Roff, 1994a, b). Determination of which set of genes will be expressed (and therefore of which phenotype will be expressed) could be governed by alleles at other loci within the genome (in the case of a genetically determined variation), or by external cues correlated with a particular agent of selection (in the case of an environmentally-determined variation). Pea aphids thus may provide the opportunity to uncover these developmental switches. An important first step in this endeavour is the thorough characterization of the genetic basis of wing polymorphism in pea aphids. In this paper, we first replicate the experiments of Smith and MacKay (1989) with clones of the pea aphid collected in a different geographical area. Then, we explore the genetic basis of wing polymorphism in males of the pea aphid by conducting crosses between winged and wingless male-producing clones. Lastly, we use microsatellite markers to determine whether the locus that controls alary polymorphism is X-linked.

\section{Materials and methods}

We designed three experiments to analyze the genetic basis of wing polymorphism in males of pea aphids. In a first experiment, we evaluated the ratio of winged vs wingless males in 16 field-collected clones. These genotypes were collected in the summer of 1998, in alfalfa fields located in the vicinity of Ithaca (NY, Tompkins county, USA), in an area of approximately 40 square miles, and on the same plant species (Alfalfa, Medicago sativa). To induce the production of sexuals, and for each of the 16 clones, five 3rd instar parthenogenetic nymphs were taken from a stock culture $\left(20^{\circ} \mathrm{C}, 16 \mathrm{~h}: 8 \mathrm{~h}, \mathrm{~L}: \mathrm{D}\right)$ and placed on alfalfa in a growth chamber at $18^{\circ} \mathrm{C}$ and a photoperiod of 13.5:10.5 (L:D). The photoperiod was then decreased every 3 days by 15 min until it reached a photoperiod of 12.5:11.5 (L:D). The temperature was then lowered to $16^{\circ} \mathrm{C}$. Six to 7 weeks after the beginning of the induction, we started collecting males which can be easily recognized by the presence of two black claspers close to the tip of the abdomen (Miyazaki, 1987). For each clone, two replicates of this experiment were performed.

In a second experiment, we performed reciprocal crosses between a clone producing only winged males (PBR8) and a clone producing only wingless males (LSR1). Sexual morphs for clones LSR1 and PBR8 were induced as described above. Six weeks after the beginning of the induction, we isolated sexual females and males from these stock cultures. In order to obtain virgin sexual females of known age, sexual females were isolated as nymphs from the stock culture and newly emerged adults were collected every day. Sexual females can be easily recognized by their thick hind tibia. Crosses were performed as described in Via (1992). Three replicates of two males and three females for each direction of the cross were established. All fertilized eggs produced throughout the life of the females were harvested, surface sterilized and placed in an incubator under daily cycles of $4^{\circ} \mathrm{C}$ during a $10 \mathrm{~h}$ day and $0^{\circ} \mathrm{C}$ during a 14-h night. After about 100 days of this cold treatment, eggs were removed from the incubator and the hatchling progeny were reared in Petri-dishes containing alfalfa foliage. Fifteen $F_{1}$ hybrid clones were obtained. Three months after these hybrid clones were initiated, thus after about six parthenogenetic generations, we chose two of them and crossed them to generate an $\mathrm{F}_{2}$ generation: winged males from one $F_{1}$ hybrid clone Fem(PBR8)*Male(LSR1) were mated to sexual females from another $F_{1}$ clone Fem(LSR1)*Male(PBR8). All resulting $\mathrm{F}_{2}$ clones were maintained under long-day conditions for 3 months, which corresponds to approximately five to eight parthenogenetic generations. We analyzed the proportion of winged versus wingless males in eight $\mathrm{F}_{1}$ hybrid clones and $97 \mathrm{~F}_{2}$ hybrid clones. For each clone, we established two replicates containing three to four third-instarnymphs, which were exposed to short-day conditions to induce the production of the sexual morphs as described above. Over the course of the following 2 months, we screened all $F_{1}$ and $F_{2}$ clones for the occurrence of winged and wingless males. Once a week, all adult males were counted, removed and their phenotype noted. For each 
clone that produced both winged and wingless males, numbers of the two morphs were tested for departure from a 1:1 ratio using a heterogeneity chi-square test (Zar, 1999).

In a third experiment, we genotyped eight field-collected clones at 10 microsatellite loci, including three that were X-linked. Microsatellites Sm10 and Sm11 were cloned from Sitobion miscanthi (Sunnucks et al, 1997) and were shown to exhibit cross-amplification for $S$. avenae by Simon et al (1999). Microsatellites S10, S16b, S17b, S23, S25, S30, S35 were also isolated from S. miscanthi (Wilson and Sunnucks submitted) while Sa5L was cloned from Sitobion avenae (JC Simon et al, unpublished). DNA from individual aphids was extracted using the 'salting-out' protocol described by Sunnucks and Hales (1996). The DNA was then resuspended in 20 to $40 \mu \mathrm{l}$ of TE buffer (10 mM Tris pH 7.5, 0.1 mM EDTA) depending on the aphid size. The amount of DNA obtained was roughly quantified by gel electrophoresis. Dilutions were then performed in order to get a DNA concentration of about 5 to $7 \mathrm{ng} / \mu \mathrm{l}$. Microsatellite amplifications were carried out in $15 \mu \mathrm{l}$ reaction mixtures consisting of 0.2 unit of Taq polymerase (Promega), $1 \times \mathrm{MgCl}_{2}$-free reaction buffer, 2 $\mathrm{mM} \mathrm{MgCl}, 200 \mu \mathrm{M}$ dNTP, $0.2 \mathrm{mM}$ of each primer and $1 \mu$ l of the diluted aphid DNA. Amplifications were made in a PTC-100 programmable thermal controller (MJ Research) using a regime of initial denaturation at $94^{\circ} \mathrm{C}$ for $3 \mathrm{~min}$, followed by 40 cycles of denaturation at $94^{\circ} \mathrm{C}$ for $1 \mathrm{~min}$, annealing for $1 \mathrm{~min}$ with temperature depending on locus and elongation at $72^{\circ} \mathrm{C}$ for 45 seconds. This was followed by an extend $72^{\circ} \mathrm{C}$ for $4 \mathrm{~min}$. For loci S10, Sm10, Sm11, Sa5L, annealing took place at $56^{\circ} \mathrm{C}$, for S23 at $58^{\circ} \mathrm{C}, \mathrm{S} 24, \mathrm{~S} 25, \mathrm{~S} 30$, and $\mathrm{S} 35$ at $62^{\circ} \mathrm{C}$ and $\mathrm{S} 17 \mathrm{~b}$ at $68^{\circ} \mathrm{C}$. A $1.8 \%$ agarose gel electrophoresis was used to check the quality of the amplification and the concentration of the PCR products. These were then diluted by half with a $4 \times$-loading buffer before electrophoresis. For each sample, about $2.5 \mu l$ (according to concentration) of the diluted PCR product was run on a $6 \%$ polyacrylamide gel (with urea present) for $2 \mathrm{~h} 30$ to 3 $\mathrm{h}$ at $1000 \mathrm{~V}$ and $75 \mathrm{~W}$ in $0.5 \times \mathrm{TBE}$ buffer. The gel was silver stained as described in Budowle et al (1991). The size of the alleles of each locus was estimated using a sequencing ladder (sequence of $\mathrm{pGEM}^{\circledR}-3 \mathrm{Zf}(+)$ vector PROMEGA). An X-OMATRA photograph of the gel was taken as a permanent document.

\section{Results}

\section{Experiment 1}

Three classes of clones were present among the 16 clones surveyed for male wing polymorphism (Table 1): seven clones produced only wingless males, two clones produced only winged males and seven clones produced winged and wingless males. In clones producing both male morphs, the number of wingless and winged males produced did not differ significantly from 1:1 in any of the clones (chi-square test, $P>0.05$ ).

\section{Experiment 2}

$\mathrm{F}_{1}$ hybrids between a clone producing only wingless males and a clone producing only winged males produced wingless and winged males in a 1:1 ratio (chisquare test, $P>0.05$, Table 2 ). The direction of the cross
Table 1 Pattern of male morph production for 16 clones (two replicates per clone). A chi-square test shows that, within a replicate, the proportions of wingless and winged males are not different $(P>0.05)$

\begin{tabular}{|c|c|c|c|c|}
\hline Clones & Replicate & $\begin{array}{l}\text { No. of } \\
\text { wingless } \\
\text { males }\end{array}$ & $\begin{array}{l}\text { No. of } \\
\text { winged } \\
\text { males }\end{array}$ & $\begin{array}{c}\text { Chi-square } \\
\text { test for } \\
\text { 1:1 ratio }\end{array}$ \\
\hline PBG7 & $\begin{array}{l}1 \\
2\end{array}$ & $\begin{array}{l}40 \\
36\end{array}$ & $\begin{array}{l}- \\
-\end{array}$ & \\
\hline LSR3 & $\begin{array}{l}1 \\
2\end{array}$ & $\begin{array}{l}78 \\
82\end{array}$ & $\begin{array}{l}70 \\
95\end{array}$ & $\begin{array}{l}\text { NS } \\
\text { NS }\end{array}$ \\
\hline FVG3 & $\begin{array}{l}1 \\
2\end{array}$ & $\begin{array}{l}24 \\
25\end{array}$ & $\begin{array}{l}27 \\
28\end{array}$ & $\begin{array}{l}\text { NS } \\
\text { NS }\end{array}$ \\
\hline LSG1 & $\begin{array}{l}1 \\
2\end{array}$ & $\begin{array}{l}32 \\
61\end{array}$ & $\begin{array}{l}26 \\
38\end{array}$ & $\begin{array}{l}\text { NS } \\
\text { NS }\end{array}$ \\
\hline PBR8 & $\begin{array}{l}1 \\
2\end{array}$ & $\begin{array}{l}- \\
-\end{array}$ & $\begin{array}{l}37 \\
44\end{array}$ & \\
\hline LSG2 & $\begin{array}{l}1 \\
2\end{array}$ & $\begin{array}{l}104 \\
101\end{array}$ & - & \\
\hline PBG3 & $\begin{array}{l}1 \\
2\end{array}$ & $\begin{array}{l}19 \\
26\end{array}$ & $\begin{array}{l}32 \\
31\end{array}$ & $\begin{array}{l}\text { NS } \\
\text { NS }\end{array}$ \\
\hline PBR2 & $\begin{array}{l}1 \\
2\end{array}$ & $\begin{array}{l}- \\
-\end{array}$ & $\begin{array}{l}21 \\
20\end{array}$ & \\
\hline LSR1 & $\begin{array}{l}1 \\
2\end{array}$ & $\begin{array}{l}64 \\
67\end{array}$ & - & \\
\hline LSG3 & $\begin{array}{l}1 \\
2\end{array}$ & $\begin{array}{l}30 \\
35\end{array}$ & $\begin{array}{l}- \\
-\end{array}$ & \\
\hline PBG4 & $\begin{array}{l}1 \\
2\end{array}$ & $\begin{array}{l}42 \\
68\end{array}$ & $\begin{array}{l}- \\
-\end{array}$ & \\
\hline FVR1 & $\begin{array}{l}1 \\
2\end{array}$ & $\begin{array}{l}45 \\
29\end{array}$ & $\begin{array}{l}- \\
-\end{array}$ & \\
\hline PBG6 & $\begin{array}{l}1 \\
2\end{array}$ & $\begin{array}{l}36 \\
51\end{array}$ & - & \\
\hline PBR7 & $\begin{array}{l}1 \\
2\end{array}$ & $\begin{array}{l}41 \\
55\end{array}$ & $\begin{array}{l}32 \\
51\end{array}$ & $\begin{array}{l}\text { NS } \\
\text { NS }\end{array}$ \\
\hline LSR2 & $\begin{array}{l}1 \\
2\end{array}$ & $\begin{array}{l}71 \\
54\end{array}$ & $\begin{array}{l}59 \\
61\end{array}$ & $\begin{array}{l}\text { NS } \\
\text { NS }\end{array}$ \\
\hline PBR1 & $\begin{array}{l}1 \\
2\end{array}$ & $\begin{array}{l}29 \\
16\end{array}$ & $\begin{array}{l}21 \\
29\end{array}$ & $\begin{array}{l}\text { NS } \\
\text { NS }\end{array}$ \\
\hline
\end{tabular}

Table 2 Pattern of male morph production for eight $F_{1}$ hybrid clones between a clone producing only wingless males (LSR1) and a clone producing only winged males (PBR8). A chi-square test shows that, within a replicate, the proportions of wingless and winged males are not different $(P>0.05)$

\begin{tabular}{lcccc}
\hline Cross & $\begin{array}{c}F_{1} \text { clone } \\
\text { no. }\end{array}$ & $\begin{array}{c}\text { No. of } \\
\text { wingless } \\
\text { males }\end{array}$ & $\begin{array}{c}\text { No. of } \\
\text { winged } \\
\text { males }\end{array}$ & $\begin{array}{c}\text { Chi-square } \\
\text { test for } \\
1: 1 \text { ratio }\end{array}$ \\
\hline Fem(PBR8)* & 1 & 72 & 54 & NS \\
male(LSR1) & 2 & 101 & 69 & NS \\
& 3 & 52 & 65 & NS \\
& 4 & 75 & 70 & NS \\
Fem(LSR1)* & 1 & 164 & 159 & NS \\
male (PBR8) & 2 & 141 & 126 & NS \\
& 3 & 75 & 86 & NS \\
& 4 & 71 & 76 & NS
\end{tabular}


Table 3 Pattern of male morph production for $47 \mathrm{~F}_{2}$ hybrid clones generated by mating a winged male from an $F_{1}$ hybrid clone to a female of another $F_{1}$ hybrid clone. A heterogeneity chi-square test shows that, overall, the proportions of wingless and winged males are not different $(P<0.05)$

\begin{tabular}{|c|c|c|c|c|c|}
\hline $\begin{array}{l}F_{2} \text { Clone } \\
\text { no. }\end{array}$ & $\begin{array}{l}\text { No. of } \\
\text { wingless } \\
\text { males }\end{array}$ & $\begin{array}{l}\text { No. of } \\
\text { winged } \\
\text { males }\end{array}$ & $\begin{array}{c}F_{2} \text { Clone } \\
\text { no. }\end{array}$ & $\begin{array}{l}\text { No. of } \\
\text { wingless } \\
\text { males }\end{array}$ & $\begin{array}{c}\text { No. of } \\
\text { winged } \\
\text { males }\end{array}$ \\
\hline 8 & 37 & 27 & 106 & 47 & 38 \\
\hline 22 & 4 & 6 & 107 & 11 & 11 \\
\hline 24 & 1 & 3 & 109 & 3 & 3 \\
\hline 25 & 34 & 26 & 113 & 20 & 13 \\
\hline 26 & 5 & 4 & 117 & 15 & 12 \\
\hline 32 & 6 & 9 & 125 & 12 & 9 \\
\hline 35 & 5 & 5 & 132 & 48 & 58 \\
\hline 38 & 2 & 3 & 136 & 13 & 21 \\
\hline 49 & 18 & 13 & 137 & 25 & 12 \\
\hline 56 & 14 & 18 & 139 & 10 & 5 \\
\hline 60 & 4 & 6 & 143 & 12 & 4 \\
\hline 61 & 16 & 8 & 157 & 11 & 9 \\
\hline 63 & 14 & 10 & 159 & 24 & 20 \\
\hline 67 & 5 & 2 & 168 & 13 & 24 \\
\hline 70 & 19 & 18 & 176 & 15 & 16 \\
\hline 73 & 9 & 13 & 189 & 20 & 29 \\
\hline 76 & 6 & 7 & 191 & 27 & 29 \\
\hline 79 & 15 & 19 & 192 & 6 & 2 \\
\hline 82 & 15 & 22 & 193 & 5 & 5 \\
\hline 84 & 16 & 13 & 196 & 19 & 8 \\
\hline 93 & 4 & 7 & 204 & 10 & 12 \\
\hline 94 & 4 & 1 & 210 & 10 & 11 \\
\hline 97 & 22 & 12 & & & \\
\hline 98 & 23 & 17 & & & \\
\hline 104 & 14 & 10 & & & \\
\hline
\end{tabular}

did not influence this ratio. Furthermore, 50 clones out of $97 \mathrm{~F}_{2}$ hybrid clones $(\sim 50 \%)$ produced only winged males while 47 clones $(\sim 50 \%)$ produced both winged and wingless males. In those 47 heterozygous clones, the number of wingless and winged males did not differ significantly from 1:1 (Heterogeneity chi-square test, $P=$ 0.41 , Table 3).

\section{Experiment 3}

Every aphid clone has a unique multilocus genotype (Table 4). We determined whether the 10 microsatellite loci were autosomal or X-linked by comparing the genotype of sexual females and males for each locus. Let us consider a microsatellite locus with two alleles, $a$ and $b$. If this locus is located on the X-chromosome, then clones that have heterozygous sexual females $\left(X^{\mathrm{a}} \mathrm{X}^{\mathrm{b}}\right)$ should also are either $\mathrm{X}^{\mathrm{a}} 0$ or $\mathrm{X}^{\mathrm{b}} 0$ ). Table 5 shows that three of the 10 microsatellites considered were X-linked. For instance, sexual females of clone LSR2 are heterozygous for locus S17b (they have alleles 216 and 218) while the males have either allele 216 or allele 218. Last, we examined the genotype of winged and wingless males for X-linked microsatellite loci S17b, S10 and Sm11 (Table 6). In clones that produce both wingless and winged males, we found that each morph inherited one of the two allele types carried by the females. Let us examine the case of LSR3 for instance. Sexual females $\left(X X^{\prime}\right)$ show two alleles for marker S10 while males ( $\mathrm{X} 0$ or $\left.\mathrm{X}^{\prime} 0\right)$, as expected, show only one allele type. However, the distribution of allele

Table 5 Genotype of eight clones (sexual females and males) at three microsatellite loci (S17b, S10, Sm11). The presence of two allelic categories within the males of heterozygous clones shows that the locus is X-linked

\begin{tabular}{|c|c|c|c|}
\hline Clones & Locus $S 17 b$ & Locus S10 & Locus Sm11 \\
\hline $\begin{array}{l}\text { LSR2 } \\
\text { Sexual females } \\
\text { males }\end{array}$ & $\begin{array}{c}216: 218 \\
216 \text { or } 218\end{array}$ & $\begin{array}{c}105: 107 \\
105 \text { or } 107\end{array}$ & $\begin{array}{c}142: 144 \\
142 \text { or } 144\end{array}$ \\
\hline $\begin{array}{l}\text { LSR3 } \\
\text { Sexual females } \\
\text { males }\end{array}$ & $\begin{array}{c}216: 218 \\
216 \text { or } 218\end{array}$ & $\begin{array}{c}113: 118 \\
113 \text { or } 118\end{array}$ & $\begin{array}{c}142: 142 \\
142\end{array}$ \\
\hline $\begin{array}{l}\text { LSG2 } \\
\text { Sexual females } \\
\text { males }\end{array}$ & $\begin{array}{c}218: 218 \\
218\end{array}$ & $\begin{array}{c}118: 118 \\
118\end{array}$ & $\begin{array}{c}142: 149 \\
142 \text { or } 149\end{array}$ \\
\hline $\begin{array}{l}\text { LSG3 } \\
\text { Sexual females } \\
\text { Males }\end{array}$ & $\begin{array}{c}218: 218 \\
218\end{array}$ & $\begin{array}{c}105: 105 \\
105\end{array}$ & $\begin{array}{c}142: 142 \\
142\end{array}$ \\
\hline $\begin{array}{l}\text { LSG1 } \\
\text { Sexual females } \\
\text { males }\end{array}$ & $\begin{array}{c}216: 218 \\
216 \text { or } 218\end{array}$ & $\begin{array}{c}105: 118 \\
105 \text { or } 118\end{array}$ & $\begin{array}{c}142: 142 \\
142\end{array}$ \\
\hline $\begin{array}{l}\text { FVG3 } \\
\text { Sexual females } \\
\text { males }\end{array}$ & $\begin{array}{c}218: 218 \\
218\end{array}$ & $\begin{array}{c}105: 118 \\
105 \text { or } 118\end{array}$ & $\begin{array}{c}142: 149 \\
142 \text { or } 149\end{array}$ \\
\hline $\begin{array}{l}\text { PBG7 } \\
\text { Sexual females } \\
\text { males }\end{array}$ & $\begin{array}{c}216: 218 \\
216 \text { or } 218\end{array}$ & $\begin{array}{c}113: 118 \\
113 \text { or } 118\end{array}$ & $\begin{array}{c}142: 142 \\
142\end{array}$ \\
\hline $\begin{array}{l}\text { PBR8 } \\
\text { Sexual females } \\
\text { males }\end{array}$ & $\begin{array}{c}218: 218 \\
218\end{array}$ & $\begin{array}{c}105: 118 \\
105 \text { or } 118\end{array}$ & $\begin{array}{c}142: 142 \\
142\end{array}$ \\
\hline
\end{tabular}

Table 4 Genotype of eight clones (parthenogenetic females) at 10 microsatellite loci. Some clones share the same genotype at a given microsatellite locus but each clone has a unique multilocus genotype

\begin{tabular}{|c|c|c|c|c|c|c|c|c|c|c|}
\hline \multirow[t]{2}{*}{ Clones } & \multicolumn{10}{|c|}{ Microsatellite loci } \\
\hline & $S 17 b$ & $S 23$ & S30 & S5.L & $\operatorname{Sm} 10$ & $S 25$ & S35 & $S 24$ & $S 10$ & $S m 11$ \\
\hline LSR2 & $216: 218$ & $135: 137$ & $172: 174$ & $205: 205$ & $150: 153$ & $135: 135$ & 109:109 & $167: 171$ & 105:107 & $142: 144$ \\
\hline LSR3 & $216: 218$ & $133: 137$ & $172: 174$ & $205: 205$ & $150: 153$ & $135: 139$ & $109: 109$ & $167: 171$ & $113: 118$ & $142: 142$ \\
\hline LSG2 & $218: 218$ & $133: 137$ & $172: 174$ & $205: 205$ & $150: 150$ & $135: 135$ & 109:109 & $167: 171$ & 118:118 & $142: 149$ \\
\hline LSG3 & $218: 218$ & $133: 137$ & $172: 174$ & $205: 205$ & $150: 153$ & $135: 135$ & 109:109 & $167: 171$ & $105: 105$ & $142: 142$ \\
\hline LSG1 & $216: 218$ & $133: 133$ & $172: 172$ & $205: 205$ & $150: 150$ & $135: 135$ & 109:109 & $167: 171$ & $105: 118$ & $142: 142$ \\
\hline FVG3 & $218: 218$ & $133: 137$ & $172: 174$ & $205: 205$ & $150: 150$ & 135:139 & 109:109 & 167:171 & $105: 118$ & $142: 149$ \\
\hline PBG7 & $216: 218$ & 133:137 & $163: 172$ & 205:205 & $150: 150$ & $135: 135$ & 109:109 & $170: 174$ & 113:118 & $142: 142$ \\
\hline PBR8 & $218: 218$ & $132: 133$ & 172:174 & $205: 207$ & $150: 153$ & $135: 135$ & 109:111 & 167:171 & $105: 118$ & $142: 142$ \\
\hline
\end{tabular}


Table 6 Genotype of sexual females, winged males and wingless males at an X-linked microsatellite locus. The male phenotype (winged or wingless) and the marker genotype cosegregate

\begin{tabular}{|c|c|c|c|c|c|}
\hline Clones & Male phenotype & X-linked locus & Sexual females genotype & Winged male genotype & Wingless male genotype \\
\hline LSR2 & Both morphs & Sm11 & 142:144 & $144(n=5)$ & $142(n=5)$ \\
\hline \multirow[t]{2}{*}{ LSR3 } & Both morphs & S10 & 113:118 & $118(n=13)$ & $113(n=14)$ \\
\hline & Both morphs & $\mathrm{S} 17 \mathrm{~b}$ & $216: 218$ & $216(n=15)$ & $218(n=15)$ \\
\hline LSG1 & Both morphs & S10 & $105: 118$ & $105(n=5)$ & $118(n=4)$ \\
\hline FVG3 & Both morphs & Sm11 & $142: 149$ & $149(n=6)$ & $142(n=5)$ \\
\hline LSG2 & $100 \%$ wingless & Sm11 & $142: 149$ & none & $142(n=3)$ OR $149(n=7)$ \\
\hline \multirow[t]{2}{*}{ PBG7 } & $100 \%$ wingless & S10 & 113:118 & none & $113(n=20)$ OR $118(n=8)$ \\
\hline & $100 \%$ wingless & $\mathrm{S} 17 \mathrm{~b}$ & $216: 218$ & none & $216(n=6)$ OR $218(n=7)$ \\
\hline PBG4 & $100 \%$ wingless & S10 & 105:107 & none & $105(n=5)$ OR $107(n=5)$ \\
\hline PBR8 & $100 \%$ winged & S10 & $105: 118$ & $105(n=4)$ OR $118(n=6)$ & None \\
\hline
\end{tabular}

types among male morphs is not random. All winged males bear one type of allele (they are all X0) while all wingless males bear the alternate allele (they are all $X^{\prime} 0$ ). In other words, variation at the S10 marker co-segregates with phenotypic variation for the presence of wings in males of pea aphids.

\section{Discussion}

The results of this study are most simply explained if male wing morph is determined by alternative alleles at a locus on the X-chromosome. If $\mathrm{Wg}$ and $\mathrm{Wl}$ represent alleles for wingedness and winglessness respectively, then sexuparae (parthenogenetic females precursors of males and sexual females) can be $X^{\mathrm{Wg}} X^{\mathrm{Wg}}$ and produce $100 \%$ of $X^{\mathrm{Wg}} 0$ males (winged), $X^{\mathrm{Wl}} X^{\mathrm{Wl}}$ and produce $100 \%$ of $\mathrm{X}^{\mathrm{Wl}} 0$ males (wingless), or $\mathrm{X}^{\mathrm{Wg}} \mathrm{X}^{\mathrm{Wl}}$ and produce $50 \%$ of $\mathrm{X}^{\mathrm{Wg}} 0$ (winged) and $50 \%$ of $\mathrm{X}^{\mathrm{Wl}} 0$ (wingless) males. If a clone that is $\mathrm{X}^{\mathrm{Wg}} \mathrm{X}^{\mathrm{Wg}}$ (such as PBR8) mates with a clone that is $\mathrm{X}^{\mathrm{Wl}} \mathrm{X}^{\mathrm{Wl}}$ (such as LSR1), then all $\mathrm{F}_{1}$ hybrid clones are $X^{\mathrm{Wg}} \mathrm{X}^{\mathrm{Wl}}$ and produce an equal proportion of winged and wingless males (Table 2). If a winged male from a $\mathrm{F}_{1}$ hybrid clone $\mathrm{X}^{\mathrm{Wg}} \mathrm{X}^{\mathrm{Wl}}$, thus carrying only $\mathrm{X}^{\mathrm{Wg}}$ since males are $\mathrm{X} 0$, mates with a female of another $\mathrm{F}_{1}$ hybrid clone $\mathrm{X}^{\mathrm{Wg}} \mathrm{X}^{\mathrm{Wl}}$, then $50 \%$ of the progeny will be $\mathrm{X}^{\mathrm{Wg}} \mathrm{X}^{\mathrm{Wl}}$ while the rest will be $X^{\mathrm{Wg}} \mathrm{X}^{\mathrm{Wg}}$. This genetic interpretation was first proposed by Smith and MacKay (1989) but it was not supported by genetic data. Our results show that wing dimorphism in male pea aphids is determined by a single sex-linked locus, hereafter called 'WgMa'. This locus appears to be sex limited in expression since sexual females do not show phenotypic variation for wing morphology, whatever their genotype at the locus $\mathrm{WgMa}$ is.

The existence of a simple genetic determinism for wing polymorphism in a system in which genetic investigation is possible may help investigations on the physiological mechanisms of genetically-based wing morph variation. Current knowledge of the precise determinants of polymorphism in general is very rudimentary (Nijhout, 1994, 1999). Wing polymorphism has been used for over a decade as a model for elucidating its physiological determinants (Zera and Denno, 1997; Roff et al, 1997). The most widely discussed hypothesis focuses on $\mathrm{JH}$ as the key regulator of wing morph variation. The juvenile hormone-wing hypothesis posits that an elevated $\mathrm{JH}$ titre during critical stages of development inhibits the full growth and differentiation of wings and/or flight muscles resulting in short-winged or wingless morphs
(Southwood, 1961; Wigglesworth, 1961). Despite considerable research effort, this hypothesis has been supported so far mostly by correlational data rather than functional data (Fairbairn and Roff, 1999; Zera, 1999). Knowledge of the causal relationship between endocrine physiology and the production of alternative wing morphs could be greatly enhanced using molecular tools because it would help identifying candidate genes responsible for the expression of alternative phenotypes. The demonstration that male alary polymorphism in $A$. pisum depends on a single locus- 2 alleles system located on the $X$ chromosome is a first step toward the molecular characterisation of a locus controlling wing morph variation.

Further analysis of the genetic basis of wing polymorphism in male pea aphids may also help elucidate the proximate control of the wing polyphenism described in parthenogenetic females. To date, most of the work on these proximate mechanisms has focused on $\mathrm{JH}$, but the evidence for the involvement of this hormone is equivocal. Some studies do not support the hypothesis that $\mathrm{JH}$ is involved in aphid wing polyphenisms (reviewed in Applebaum and Heifetz, 1999). Other studies reported that application of anti-JH agents induced the production of winged individuals (Mackauer et al, 1979; Delisle and Cloutier, 1980). In one case, application of JH caused the winged precursors of sexual females to develop into wingless individuals but a similar experiment carried out on regular parthenogenetic females showed no effect of JH application (Hardie, 1980). Location and characterization of the gene controlling male wing polymorphism in pea aphids would provide a candidate gene to test $\mathrm{JH}$ function during polyphenic development. Suppression of this gene could cause asexual females to produce only one of the phenotypes regardless of the presence or absence of relevant environmental stimuli. Furthermore, variation at the locus controlling the male wing polymorphism could account for variation in the propensity to produce winged offspring of parthenogenetic females. Pea aphid clones show considerable variation in the production of winged offspring when exposed to the same environmental stimulus, suggesting that there is heritable variation in the sensitivity to the environmental cue governing morph production (Lamb and MacKay, 1979, 1983; Weisser and Braendle, 2001). This could be tested by analyzing genetic variation in the production of winged offspring and molecular variation in the vicinity 
of (and eventually at) the WgMa locus, for a set of fieldcollected clones.

If the locus controlling male wing polymorphism in the pea aphid is also involved in the wing polyphenism during the asexual generations, this may help understanding the interplay between polymorphisms and polyphenisms. Several lines of evidence suggest that they involve similar genetic and developmental architectures. First, phenotypes developed under environmental or genetic control are sometimes strikingly similar. In the case of variation in wing morphology in aphids for instance, genetically-induced winged individuals and environmentally-induced individuals are similar in many morphological features including the structure of the sensory system (eg, Kring, 1977). Second, in many instances a similar alternative phenotype is expressed as an environmentally controlled polyphenism in some species and as a genetically controlled polymorphism in another (closely related) species (Nijhout, 1999). Third, a similar phenotype can be determined by either the environment or variation at a single locus. In the buckeye butterfly, Precis coenia, the autumn morph is most of the time induced by low temperature and short days, but there is also a gene (rosa) whose recessive allele produces the autumn phenotype when homozygous (Rountree and Nijhout, 1995). It appears likely that there is a physiological/functional link between polyphenisms and polymorphisms, but it remains unclear whether a genetically controlled polymorphism could evolve from an environmentally controlled polyphenism (or vice versa). As discussed by Nijhout (1999), once a polyphenism has been established, it is possible for one or the other morph to become fixed in a population. This is seen as advantageous if the population enters a habitat that is not favorable for induction of the polyphenic switch (West-Eberhard, 1989). A polymorphism-to-polyphenism transition could also be achieved. If the genetic effect was originally mediated by the endocrine system, there are many ways in which hormone secretion, metabolism, thresholds, or sensitive periods, could be made responsive to environmental variation (Nijhout, 1999). At present, insufficient genetic, endocrine, or developmental information is available to examine the evolutionary transition between polymorphism and polyphenism. The coexistence of both a polyphenism and a polymorphism creating the same alternative phenotypes in a single organism, and a single genotype, gives the pea aphid the potential to become a key model in the study of this transition.

\section{Acknowledgements}

This work was supported by a Hatch grant (Cornell University) to MCC. CB was supported by the Boehringer Ingelheim Fonds, the Roche Research Foundation, and the Janggen-Poehn-Stiftung. Bryan Danforth (Cornell University, USA) and Manuel Plantegenest (Ecole Nationale Superieure Agronomique de Rennes, France) read an early version of this manuscript.

\section{References}

Applebaum SW, Heifetz Y (1999). Density-dependent physiological phase in insects. Annu Rev Entomol 44: 317-344.

Blackman RL (1987). Reproduction, cytogenetics and development. In: Minks AK, Harrewijn P (eds) Aphids, Their Biology,
Natural Enemies and Control, vol. 2A, Elsevier: Amsterdam. pp 163-196.

Budowle B, Chakraborty R, Giusti AM, Eisenberg AJ, Allen RC (1991). Analysis of the VNTR locus D1S80 by the PCR followed by high-resolution PAGE. Am J Hum Genet 48: 137-144.

Delisle J, Cloutier CF (1980). A study of morph determination in the potato aphid using precocene, a compound with antijuvenile hormone activity. Abstracts of the XVI International Congress of Entomology, Kytoto, Japan.

Dingle H, Winchell R (1997). Juvenile hormone as a mediator of plasticity in insect life histories. Arch Insect Biochem Physiol 35: 359-373.

Fairbairn DJ (1994). Wing dimorphism and the migratory syndrome: correlated traits for migratory tendancy in wing dimorphic insects. Res Popul Ecol 36: 157-163.

Fairbairn DJ, Roff DA (1999). The endocrine genetics of wing polymorphism in Gryllus: a response to Zera. Evolution 53: 977-979).

Hardie J (1980). Juvenile hormone mimics the photoperiodic apterization of the alate gynopara of aphid, Aphis fabae. Nature 286: 602-604.

Hardie J, Lees AD (1985). Endocrine control of polymorphism and polyphenism. In: Kerkutand GA, Gilbert LI (eds) Comprehensive Insect Physiology, Biochemistry and Pharmacology: vol. 8, Pergamon Press: New York. pp 441-449.

Harrison RG (1980). Dispersal polymorphism in insects. Ann Rev Ecol Syst 11: 95-118.

Hazel WN, Mock RS, Johnson MD (1990). A polygenic model for the evolution and maintenance of conditional strategies. Proc $R$ Soc Lond B Biol Sci 242: 181-187.

Kring JB (1977). Structure of the eyes of the pea aphid, Acyrthosiphon pisum. Ann Ent Soc Am 70: 855-860.

Lamb RJ, Mackay PA (1979). Variability in migratory tendency within and among natural populations of the pea aphid, Acyrthosiphon pisum. Oecologia 39: 289-299.

Lamb RJ, Mackay PA (1983). Micro-evolution of the migratory tendency, photoperiodic response and developmental threshold of the pea aphid, Acyrthosiphon pisum. In: Brown VK, Hodek I (eds) Diapause and Life Cycle Strategies in Insects. Dr W Junk Publishers: The Hague. pp 209-217.

Mackauer M, Nair KK, Unnithan GC (1979). Effects of precocene II on alate production in the pea aphid, Acyrthosiphon pisum. Can J of Zool 57: 856-859).

McCaffery AR, Page WW (1978). Factors influencing the production of long-winged Zonocerus variegatus. I Insect Physiol 24: $465-472$

Miyazaki M (1987). Morphs and morphs of aphids. In: Minks AK, Harrewijn P (eds) Aphids, Their Biology, Natural Enemies and Control, vol. 2A, Elsevier: Amsterdam. pp 27-50.

Nijhout HF (1994) Insect Hormones. Princeton University Press: Princeton.

Nijhout HF (1999). Control mechanisms of polyphenic development in insects. Bioscience 49: 181-192

Nijhout HF, Wheeler DE (1982). Juvenile hormone and the physiological basis of insect polymorphisms. Q Rev Biol 572: 109-133.

Orlando E (1974). Sex determination in Megoura viciae: Homoptera: Aphididae. Monit Zool Ital 8: 61-70.

Pough RH (1951). Audbon Water Bird Guide. Doubleday: New York.

Roff DA (1986). The evolution of wing dimorphisms in insects. Evolution 40: 1009-1020.

Roff DA (1994a). The evolution of dimorphic traits: predicting the genetic correlation between environments. Genetics 136: 395-401.

Roff DA (1994b). The evolution of dimorphic traits: effects of directional selection on heritability. Heredity 71: 36-41.

Roff DA, Fairbairn DJ (1991). Wing dimorphisms and the evolution of migratory polymorphisms among the insecta. Am Zool 31: 243-251.

Roff DA, Stirlings G, Fairbairn DJ (1997). The evolution of thres- 
hold traits: a quantitative genetic analysis of the physiological and life-history correlates of wing dimorphism in the sand cricket. Evolution 51: 1910-1919).

Rountree DB, Nijhout HF (1995). Genetic control of a seasonal morph in Precis coenia (Lepidoptera: Nymphalidae). J Insect Physiol 41: 1141-1145

Simon JC,Baumann S, Sunnucks P, Hebert PDN, Pierre JS, LeGallic JF, Dedryver CA (1999). Reproductive mode and population genetic structure of the cereal aphid Sitobion avenae studied using phenotypic and microsatellite markers. Mol Ecol 8: $531-545$

Smith MAH, Mackay PA (1989). Genetic variation in male alary polymorphism of pea aphid, Acyrthosiphon pisum. Entomol Exp Appl 51: 125-132.

Southwood TRE (1961). A hormonal theory of the mechanisms of wing polymorphism in Heteroptera. Proc Roy Entomol Soc Lond (A) 36: 63-66.

Sunnucks P, Hales D (1996). Numerous transposed sequences of mitochondrial cytochrome oxydase I-II in aphids of the genus Sitobion (Hemiptera: Aphididae). Mol Biol Evol 13: 510-524.

Sunnucks P, De-Barro PJ, Lushai G, MacLean N, Hales D (1997). Genetic structure of an aphid studied using microsatellites: cyclic parthenogenesis, differentiated clones and host specialization. Mol Ecol 6: 1059-1073.

Tan CC (1946). Mosaic dominance in the inheritance of color patterns in the lady-bird beetle, Harmonia axyridis. Genetics 31: 195-210.
Via S (1992). Inducing the sexual morphs and hatching the eggs of pea aphids. Entomol Exp Appl 65: 119-127.

Weisser WW, Braendle C (2001). Body colour and genetic variation in winged morph production in the pea aphid. Ent Exp Appl 99: 217-223.

West-Eberhard MJ (1989). Phenotypic plasticity and the origins of diversity. Ann Rev Syst Ecol 20: 249-278.

West-Eberhard MJ (1992). Behavior and evolution. In: Grant PR, Grant HS (eds) Growing Points in Evolutionary Biology. Molds, Molecules and Metazoa, Princeton University Press: Princeton. pp 57-75.

Wigglesworth VB (1961). Insect polymorphism-a tentative synthesis. Symp Roy Entomol Soc Lond 1: 103-113.

Wilson EO (1971). The Insect Societies. Belknap Press: Cambridge.

Wilson ACC, Sunnucks P, Hales DH (1997). Random loss of X chromosome at male determination in an aphid, Sitobion near fragariae: detected using and X-linked polymorphic microsatellite marker. Genet Res 69: 233-236.

Zar JH (1999). Biostatistical Analysis. Prentice-Hall. Englewood Cliffs, NJ.

Zera AJ (1999). The endocrine genetics of wing polymorphism in Gryllus: critique of recent studies and state of the art. Evolution 53: 973-976.

Zera AJ, Denno RF (1997). Physiology and ecology of dispersal polymorphism in insects. Annu Rev Entomol 42: 207-231. 